\title{
The Role and Heterogeneity of Visual Pollution on the Quality of Urban Landscape Using GIS; Case Study: Historical Garden in City of Maraqeh
}

\author{
Parisa Nami1 ${ }^{*}$, Parvin Jahanbakhsh' ${ }^{1}$, Arefe Fathalipour ${ }^{2}$ \\ ${ }^{1}$ Department of Geography and Urban Planning, Malekan Branch, Islamic Azad University, Malekan, Iran \\ ${ }^{2}$ Department of Urban Planning, Marand Branch, Islamic Azad University, Marand, Iran \\ Email: parisanamii@gmail.com
}

Received 30 December 2015; accepted 24 January 2016; published 27 January 2016

Copyright (C) 2016 by authors and Scientific Research Publishing Inc.

This work is licensed under the Creative Commons Attribution International License (CC BY). http://creativecommons.org/licenses/by/4.0/

(c) (i) 0pen Access

\section{Abstract}

The urban landscape heterogeneity has been influenced by the visual, unpleasant and unacceptable face of which there is no charm in it. The present study is formed according to visual pollution and its impact on the appearance and vitality of a city. Preliminary studies and theoretical studies led to the hypothesis with the following themes: 1) There is relationship between the pollution, heterogeneity and visual disturbances urban landscape and urban vitality; 2) Improving the quality, aesthetics and identity of public spaces will increase urban vitality. Therefore, the design process within the theoretical principles, concepts, television and urban landscape, urban art, visual pollution aspects (color, light, and visual symbol) and the quality of urban vitality and explain causal relationships, analytical framework developed and more samples case (garden historic town of Maraqeh ${ }^{1}$ ) and the area under study were selected using GIS. After designing the questionnaire to evaluate the objectives, assumptions and questions of research and its analysis, the results indicate that the relationship between visual pollution and urban vitalitys, as well as proving hypotheses and vitality after the final analysis, model was introduced based on the components of comfort visual editing and proposed at three levels: micro, middle and macro for objectives, strategies and policies to regulate visual pollution and improve the aesthetic quality of the environment and the promotion of vitality.

\footnotetext{
"Corresponding author.

${ }^{1}$ Maraqeh, as the first Mongolian capital with the richness of more than 300 important monuments is one of 10 cities with monuments from different periods, the effect on the national index registered 13 and with respect to natural features (plains and highland). More than $61.3 \%$ of the land area of the city of Maraqeh vegetation that face of the city is garden and wooded streets and urban garden setting. 


\section{Keywords}

\section{Urban Landscape, Visual Pollution, Urban Vitality, Quality}

\section{Introduction}

\subsection{Expressing the Problem}

In today's world, people are encountered with environmental pollution coming from different dimensions including a visual pollution in cities as far more and deeper wounds on the face has the impact on the urban areas the outcome of the citizens and its outcome is the misidentify of the ravages of unbridled cities. And because the rigorous study has not been done to evaluate the effect of visual pollution, it is thought to have less consequence than other contaminants [1].

Plenty of space-spirited, cold and lifeless are in our cities that can be seen that do not induce any meaning, concept and performance far from any beauty and utility, as in the evaluation of The Economist in Stock in lively 2012, Tehran as the Iranian capital $\left(132^{\text {th }}\right.$ among 140 cities around the world) is not in a particularly good position [2].

There is so wrong in defining the structure of urban and public spaces that visual chaos has become a common problem in urban areas and citizens are going there solely because of their daily essential needs in these areas are now thought to be the part of urban life. And "visual comfort, improve the quality of environment, beautification and urban vitality, joy and satisfaction of citizens" comes as the missing link between citizens and urban spaces and often little attention is paid to planning and urban design as one of the important objectives and strategies to be considered [3].

\subsection{The Importance of and Need for Research}

"Relaxing, calm space and reduce pollution and regulate urban graphics and visual art" and immunity of citizens of psychological harms of visual disturbances in the environment are the most important productive factors the quality of human life. So the contaminated heterogeneous urban landscape through planning, legislation and full participation in the beautification of the urban visual landscape and creating vitality for peace as a result of the urban environment has become increasingly important as the beauty and vitality of a city to be felt significantly in these places and all ages and social sex with a sense of security and safety can be present in these spaces. See Table 1.

\subsection{Project Goals and Research Questions}

1) Organizing urban public spaces with an emphasis on reducing visual pollution and visual disturbances resolved to increase the desirability, attractiveness and satisfaction, and evaluate effective strategies in creating a vibrant urban spaces;

2) Improve the quality of urban aesthetic including visual, safety, environmental and functional quality;

3) Considering the principle of people towards the urban art and design attractive spaces, beautiful and vibrant city.

Based on the goals, the following questions have been raised in the context of this study:

1) Is the visual pollution due to lack of charm, quality and vitality in urban areas?

2) Is it possible to increase the vitality using the organization the visual pollution and improve environmental quality?

3) What practical solutions can organize the visual pollution and disturbances in the organization of the urban landscape?

\subsection{Literature}

Many experts have dealt with explaining the promotion of the beauty, vitality, quality of urban space and subject matter. Jicobs in "The Death and Life of America's great cities" [4], expresses the standards creating diversity 
Table 1. Favorable environmental qualities of urban spaces highlighted by experts.

\begin{tabular}{|c|c|c|c|c|c|}
\hline \multicolumn{3}{|c|}{ Kevin Leach “good shape of city” 1981} & \multicolumn{3}{|c|}{ Ian Bentley’s “responsive environment” 1985} \\
\hline Vitality & Meaning & Compatibility & Permeability & Diversity & Readability \\
\hline Convenience & Supervision \& control & 6-efficiency & Flexibility & Visual compatibility & Sensory richness \\
\hline \multicolumn{3}{|c|}{ Death and Life of America's great cities 1961} & \multicolumn{3}{|c|}{ Perspectives for a New American Dream 1994} \\
\hline 1-mixed-use & Emphasize on street & Convenient user & Human scale & Street view & Accountability \\
\hline Social incorporation & Permeability & & $\begin{array}{c}\text { Promoting } \\
\text { pedestrian-oriented }\end{array}$ & Outdoor forecast & Mixed-use \\
\hline \multicolumn{6}{|c|}{ Making good cities for people } \\
\hline & & & \multicolumn{3}{|c|}{ Opportunities for innovation in Training of urban design 1987} \\
\hline Human scale & Moving walks & $\begin{array}{l}\text { General and specific } \\
\text { space }\end{array}$ & Vitality \& diversity & $\begin{array}{l}\text { Design for } \\
\text { implementation }\end{array}$ & $\begin{array}{l}\text { Recreational and } \\
\text { cultural environment }\end{array}$ \\
\hline 1-mixed-use & Visual richness & Urban Management & $\begin{array}{l}\text { Architectural environment, } \\
\text { historic preservation and } \\
\text { urban restoration }\end{array}$ & & \\
\hline $\begin{array}{l}\text { Cleanliness and } \\
\text { security }\end{array}$ & Identity & $\begin{array}{l}\text { Dimension of } \\
\text { esigning urban planning }\end{array}$ & & & \\
\hline \multicolumn{3}{|c|}{ Dimension of designing urban planning 1997} & \multicolumn{3}{|c|}{ Quality urban design 1993} \\
\hline $\begin{array}{l}\text { Environmental } \\
\text { sustainability }\end{array}$ & $\begin{array}{l}\text { Quality of urban } \\
\text { form }\end{array}$ & Quality vision & Vitality \& diversity & Harmony and diversity & Personalized possibility \\
\hline $\begin{array}{l}\text { Quality urban } \\
\text { landscape }\end{array}$ & Quality public realm & $\begin{array}{l}\text { Quality construction } \\
\text { form }\end{array}$ & Controlling development & Richness & Flexibility \\
\hline
\end{tabular}

and attractiveness contribute to the vitality of the urban environment with emphasis on the social aspect of streets, sidewalks, and parks. Lynch "theory of the City" [5], in a large-scale study of urban vitality believed that vibrancy along with the meaning, relevance, access, control and discretion, efficiency and justice are functional axes forming a good city. Cullen in "The Selection landscape" [6], with investigating the effects of aesthetic and sensory experience of urban space and visual appeal (places and content), has considered thee heterogeneity (pollution) in the visual appearance of the floor, walls and street art of visual and believes that structural integrity (identity) to set the location of the city and social investment and a sense of ownership of the space are the living standard of urban space and understanding the vitality. Dandis in "visual literacy principles" [7], has dealt with to expressing the effects of graphics and urban art and aesthetics, contrast, harmony and balance in urban on space and the citizens understand the meaning and message of visual (visual literacy). Carmona in "public places and spaces" [8], has investigated visual, aesthetic, cognitive, social, functional aspects of designing a public place. BA, Ashihara in "aesthetic landscape" [9], emphasizing the place and the people in the urban landscape and has examined the scope of architectural space, composition, landscape, painting memorable spaces and aesthetic elements urban landscape.

\section{Theoretical Foundations}

\subsection{Of Urban Landscape}

According to Kevin Lynch, urban landscape is part of the city that comes to mind is lodged seen and cause for joy. The main factors for constructive are way, node, neighborhoo, edges and tokens [4].

Urban Landscape is the art of visual and structural integrity of the buildings, streets and places that make the city environment and the art of constructive communication between different parts of the body [10]. See Figure 1.

\subsection{Visual Pollution}

Visual pollution is "unbridled and uncoordinated diversity of color, form, light and materials and the accumulation of heterogeneous visual elements, ugly, unattractive and man-made space and urban landscape, and is an 


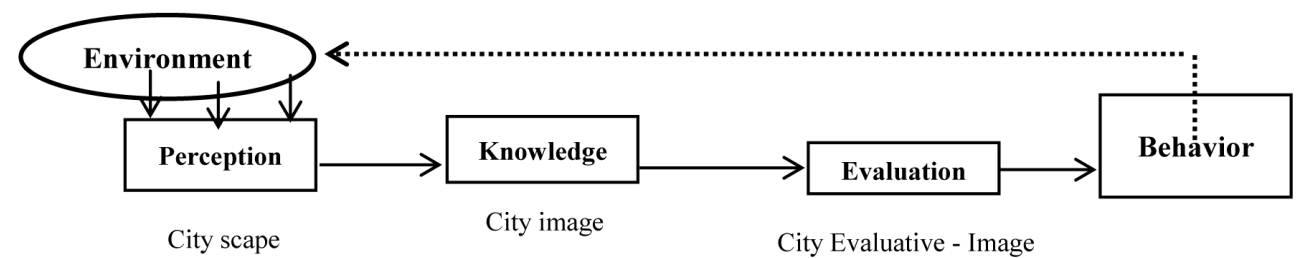

Figure 1. Conceptual model [11].

aesthetic issue and its effects one's ability to enjoy the sights reduced or view it disrupts”, which is divided in different dimensions:

Visual pollution, is confusion and visual pollution in urban public space experience, most within the location (street and square) which is the main field of the visual experience and the mental picture of it-and the more the body in the form of street furniture, volumes and elements and ugly extensions, walls and tables, sidewalks, flooring and walls, architecture, facade construction, outdoor advertising and urban, spaces abandoned and dilapidated, buildings and monuments of art, history, religion and business are destroyed.

Light pollution is synonymous with phrases such as Pollution Light Pollution; Luminous shows the negative effects of improper lighting, improper use of light sources and a mismatch between the lighting and the location [12]. The most obvious sign of the improper use of light sources in the urban environment and the lack of compatibility with the space, lack of environmental lighting, lighting disturbing lack of proper guide lighting and lack of lighting.

\section{Color Pollution}

Color of the elements affecting the incidence of visual pollution and heterogeneity of urban landscape into a canvas identity and role in increasing feelings and emotions, enhancing beauty and environmental impact is a factor to define the space, enhance readability, sense unity, and identity and create a sense of place [13]. So the color pollution includes "adverse visual landscape due to uneven application of color and human perception of color is the cause of unhappiness and unpleasant visual impact on the urban landscape".

\section{Symbol Pollution}

Symbols, monuments, old town and a general indication are the important factors for understanding the city. Clear image, good and certain environment, a person a sense of peace and security and create an accurate picture of the city in mind that if the visual aspect is to strengthen the means it was increased [14]. Symbol pollution includes "any disruption in any of the two elements that concept conception occurs and receiving messages, a clear picture and understanding of the environment it is difficult" such as the existence of vague information, numerous other understandable and relevant to the location.

\subsection{Quality}

Golkar believes that quality is used to describe the perfection of things and phenomena resulting form (formal or formal quality), performance (quality performance) and meaning (semantic quality) [11].

\subsection{Activity}

Vitality, dynamism and attractiveness of urban space in front of the dismal is the reflection of the type of activity that takes place in space. Ian Gehl has divided activities into 3 categories: Essential (mandatory), optional (health) and, social activities. In a nice city, not only essential activities are in good condition but many people's favorite leisure, social activities are done and the city offers quality, tempting and, attractive spaces [6].

\subsection{Vitality and Lively Urban Space Alive}

Dr. Golkar assumes the vitality is equal to "Livability and liveliness" that it depends on the achievement of desirable qualities such as urban design, legibility, color belonging, inclusion, flexibility, visual character, learners, the quality of public areas, together with the nature, sense time, energy, climatic comfort, permeability and movement, sensory richness, safety and security, user mix and form efficiency and environmental cleanliness, along with vitality, "the overall quality of urban design" [11]. According to the definitions, quality, activity and vitality of a "lively urban space" include "the place where significant presence of people and their diversity (in 
terms of age and gender) in a wide range time (night and day) that their activities are mainly in the form of social choice and has two procedures [9]. A procedure is dependent on insight and understanding of their culture and the other is related to the quality, beauty and architecture of the urban spaces that are interrelated".

\subsection{City Art or Its Graphic}

The result is a series of communications and procedure that offers systematic visual representations of lubricating seen, the quality of forming in the environment and development in the light of the aesthetic and the functional presentation of [8].

The goals of Urban Graphic include:

-Identity, dignity and readability of urban space-relax and soften the space, reducing the severity of mental suffering caused visual;

-promoting visual culture, visual and coordination with art and urban furniture;

-The development of urban and visual art in the design and implementation of lasting quality in the city, based on scientific principles;

-Organization of color and light, urban furniture, graphics, and visual behavior in the urban environment to suit urban elements and space General.

Bob Jarvis in "urban environment as visual art” believes that the traditions of city art thinking include visual aesthetic traditions, social customs and traditions make the city a place of integration of aesthetics and social tradition, and the guidance of art create urban location, identity, quality public space, ease of mobility, readability, compatibility, variation, qualities of visual and aesthetic experiences [15].

\section{Methods}

Research was done in 7 phases: initial question, exploratory studies, conceptual design research, analytical modeling, observation, analysis, conclusions, taken [16], which has an "applied purpose" and data is quantitative and a qualitative assessment has been done on them. The study also is a "field study" based on the characteristics of the "solidarity work". The view includes focus groups and direct observation (mapping behavioral and imaging). The sample was estimated by Cochran formula 250, consisting of two groups of experts (systematic sampling) and citizens (random sampling available). Face and content validity of the questionnaire endorsed by prominent scholars and its coefficient Cronbach's alphais 0.853 that its reliability level is very good. After extraction of information through the SPSS, in order to determine the distribution of data, Kolmogorov-Smirnov test was used, to determine the average state variables of the "single-sample T-test" and "T-test", to compare rank variables "Friedman", to examines the relationship between independent variables and the dependent variables of the "analysis of variance" was is used.

\section{Determining the Scope of Study}

For selecting of the problematic area having highest visual pollution, yet the beauty, charm, and vitality readability in low levels in those spaces is evident, after determining the coordinates of 425 points (public spaces) and scoring intensity maps Statistics Center pollution, over 1700 information code was determined and completed based on the output map GIS most polluted urban environment Maraqeh, accordingly street in the city center, adjacent to New Street Nasir heaven and jam, as well as urban areas with very specific visual pollution Maraqeh is located in the historical context-which often is the destruction, are, in spite of centers and commercial activity, a great deal of visual disturbances in the body, improper walking floor spaces with fences, extensions, open canals, unbridled urban advertising, poor lighting, lack of lighting, street furniture ugly and inefficient, lack of color balance found dead. In summary, an urban environment cool and the lack of appropriate space can be seen that the majority of citizens spend their time due to their essential needs (see Table 2).

\section{Analysis}

\subsection{Direct Conclusion}

According to the present status, pollution and visual diversity of urban areas studied range in size (visual, color, light, Symbol) is provided in the form of images and spatial analysis (see Figure 2). 

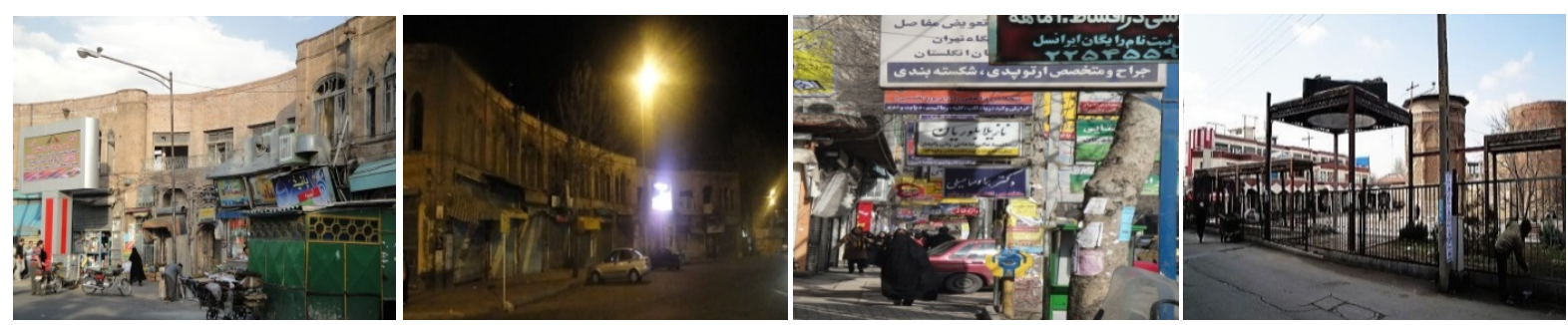

Figure 2. Part of visual pollution in the study area, Source: Authors.

Table 2. Descriptive characteristics of the sample group.

\begin{tabular}{|c|c|c|c|c|c|c|c|}
\hline \multicolumn{2}{|c|}{ Variable } & \multirow{2}{*}{$\begin{array}{c}\text { Frequency } \\
100\end{array}$} & \multirow{2}{*}{$\begin{array}{c}\text { Percent } \\
40\end{array}$} & \multicolumn{2}{|r|}{ Variable } & \multirow{2}{*}{$\begin{array}{c}\text { Frequency } \\
122\end{array}$} & \multirow{2}{*}{$\begin{array}{r}\text { percent } \\
48.8\end{array}$} \\
\hline & Experts & & & & Practitioner & & \\
\hline 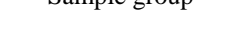 & Citizens & 150 & 60 & & Non-working & 20 & 8.0 \\
\hline \multirow{2}{*}{ Gender } & Male & 145 & 58.0 & \multirow{2}{*}{$\begin{array}{l}\text { Activity } \\
\text { status }\end{array}$} & Housewife & 23 & 9.2 \\
\hline & Female & 105 & 42.0 & & Studying & 55 & 22.0 \\
\hline \multirow{4}{*}{$\begin{array}{l}\text { Familiarity with \& } \\
\text { belonging to Maraqeh }\end{array}$} & Born in Maraqeh & 213 & 85.0 & & Income without working & 9 & 3.6 \\
\hline & Residents of Maraqeh h & 37 & 14.8 & & Other... & 21 & 8.4 \\
\hline & High school & 17 & 6.8 & & 20 years and under & 17 & 6.8 \\
\hline & Diploma & 32 & 12.8 & & $21-30$ & 100 & 40.0 \\
\hline \multirow[t]{3}{*}{ Education } & Technician & 37 & 14.8 & 1. & $31-40$ & 92 & 36.8 \\
\hline & Bachelor & 115 & 46.0 & & Over 40 & 41 & 16.4 \\
\hline & MA or higher & 49 & 19.6 & & Total & 250 & 100 \\
\hline
\end{tabular}

\subsection{Indirect Conclusion}

According to the research subject, questionnaire designing has been based on the criteria outlined in the theoretical foundations. Table 2 shows the descriptive characteristics (frequency, percent) of the sample group:

In posing the question of "beauty, calm, charm, vitality and vibrancy of the urban environment and public spaces for citizens" $37.60 \%$ announced very high, $39.60 \%$ high, $20.80 \%$ somewhat, $1.60 \%$ low and $0.40 \%$ at the very least (Figure 1). In question "the impact of visual disturbances and pollution on the presence in the study area" $12 \%$ declared high, high $44.80 \%$, 36\% somewhat and finally $7.2 \%$ declared that that the visual pollution has a low and very low effect on them (see Figure 3, Figure 4).

In the next step, of the sample was asked to specifies "the reasons priority for their presence in urban areas (study area)". This question is proposed according to Ian Gel activity in determining the vitality and dynamism of urban spaces. Based on the SPSS data output, essential activities (mandatory) is the most important reason of the people for being present in urban public spaces that it would show a lack of attractiveness, vitality within the scope of the study (see Table 3).

In response to the question "how much is the visual pollution effectiveness on beauty, attractiveness, vitality and vibrancy of urban spaces Maraqeh?” the results show that the impact of visual pollution was very high and high on urban space (see Figure 5).

In the question of Table 5 which was mainly on analysis and theoretical foundations of research, the idea of people was questioned on the impact of effective factors related to Quality, beauty, charm, liveliness, vitality, and visual comfort of urban space.

In the next question, criteria related to theoretical foundations were addressed in relation to the characteristics of the urban public space, beautiful, charming, vivacious, and lively and respondents were asked to prioritize according to their importance from one to 10 . The variable has the highest priority is the lowest rank (see Table 4). 


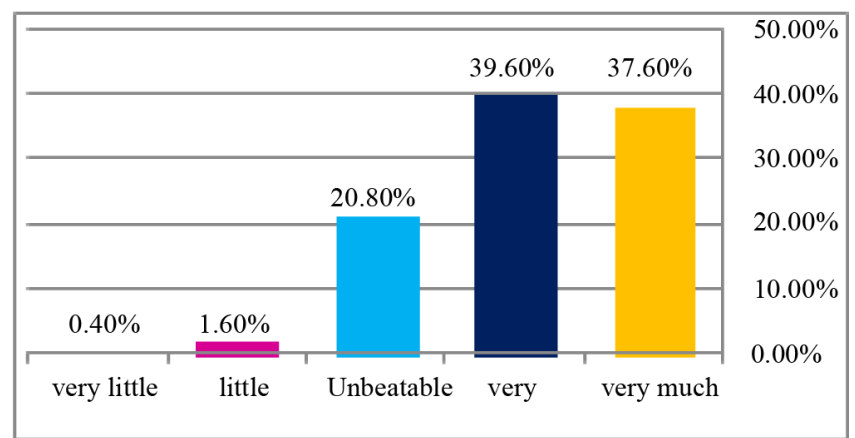

Figure 3. Importance of beauty, relaxation, vitality and vibrancy of urban spaces.

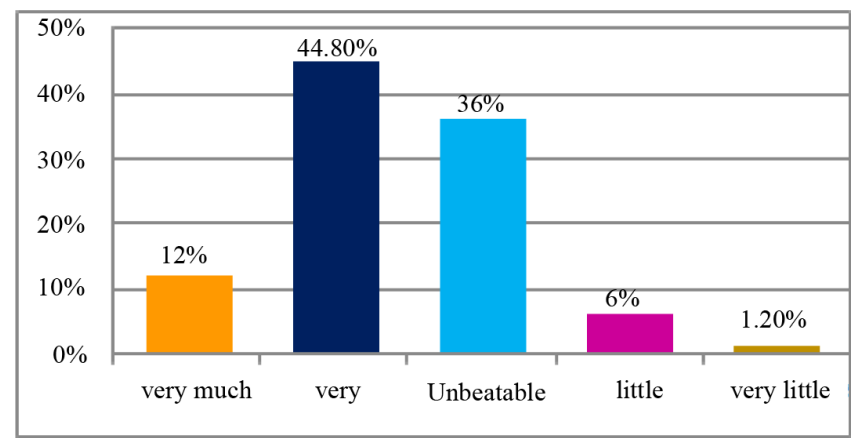

Figure 4. Importance of visual pollution impact on the citizens in urban areas.

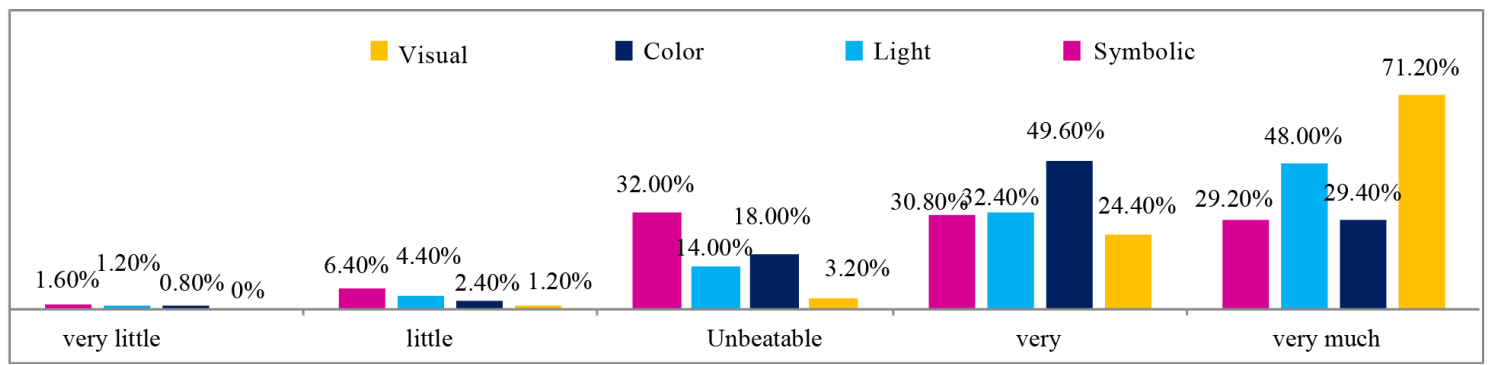

Figure 5. The effect of visual pollution on beauty, vitality of urban spaces.

Table 3. Friedman test to prioritize reasons for participating in the study area.

\begin{tabular}{cccccc}
\hline Varible & Number & Mean & Average Rating & Chi-square value & Degrees of freedom \\
\hline Buying, go to work & 250 & 1.46 & 1.46 & & \\
Travel and leisure & 250 & 2.48 & 2.48 & 267,586 & 4 \\
Visiting, meeting, stroll & 250 & 2.77 & 2.77 & \\
Other goals & 250 & 3.3 & 3.29 \\
\hline
\end{tabular}

Statistical Analysis

Before performing the test, to determine the normal distribution of data, the Kolmogorov-Smirnov test was used (see Table 5).

One sample T-test was used to assess the first and second hypotheses. As the significance level is less than 0.05 , and the mean is greater than 3 , the null hypothesis $\left(\mathrm{H}_{0}\right)$ is rejected in both the hypothesis. We conclude that:

(H1) the effect of visual pollution on urban vitality is significantly more than average and the first assumption proved. 
Table 4. Distribution of the factors affecting the promotion of quality, beauty, charm, liveliness, vitality, visual comfort and stylized urban space.

\begin{tabular}{|c|c|c|c|c|c|}
\hline Factors & Very low & Low & Somewhat & Much & Very much \\
\hline $\begin{array}{l}\text { Restore and beautify buildings and monuments of historical, artistic, } \\
\text { religious, cultural and ... }\end{array}$ & - & 1.6 & 6.0 & 34. 8 & 57.6 \\
\hline Proper use of urban furniture, volumes, elements, elements and... & - & 0.8 & 21.2 & 46.8 & 31.2 \\
\hline Diversify and strengthen urban green space and vegetation & 2.0 & 1.2 & 29.2 & 28.8 & 38.8 \\
\hline Improvement and beautification of the space walk & - & 4.0 & .814 & 38.4 & 42.8 \\
\hline Ceremony and celebration of cultural, artistic and... & 0.8 & 3.2 & 34.4 & 33.2 & 28.4 \\
\hline $\begin{array}{l}\text { Creating an interactive space and enough space to sit and pedestrian walking } \\
\text { areas }\end{array}$ & 0.4 & 2.4 & 20.8 & 35.2 & 41.2 \\
\hline Emphasize architectural identity and organization building facades & 1.2 & 10.8 & 29.2 & 30.8 & 28.0 \\
\hline Shopping, restaurants, entertainment and... & 0.8 & 5.6 & 21.2 & 31.6 & 40.8 \\
\hline $\begin{array}{l}\text { Organizing elements and urban outdoor advertising (signs advertising } \\
\text { commercial, advertisement, poster, billboard, graffiti, stickers, flyers, leaflets, } \\
\text { banners, etc.) }\end{array}$ & 1.2 & 4.4 & 22.4 & 38.0 & 34.0 \\
\hline $\begin{array}{l}\text { The use of lighting and lighting of spaces and street furniture and lighting } \\
\text { principles, artwork, historical elements and... }\end{array}$ & - & 3.2 & 13.6 & 32.0 & 51.2 \\
\hline Creating a colorful and standards in the use of color in the city & 0.4 & 4.0 & 16.0 & 41.6 & 38.0 \\
\hline Social security and the safety of pedestrians (cars) & 1.2 & 4.4 & 20.4 & 36.8 & 37.2 \\
\hline $\begin{array}{l}\text { Remove extensions unseemly elements (air channels, pipe installation gas, } \\
\text { electricity and telephone lines, blinds and awnings shops, studs, etc.) }\end{array}$ & 0.4 & 4. 8 & 31.2 & 31.2 & 32.4 \\
\hline Improvement, organize and beautify abandoned and dilapidated urban spaces. & 0.4 & 5.2 & 19.2 & 33.6 & 41.6 \\
\hline $\begin{array}{l}\text { Development, improvement and beautification of public perspectives and } \\
\text { legible visual milestones and landmarks of the city }\end{array}$ & 1.2 & 6.4 & 27.2 & 40.0 & 25.2 \\
\hline User distribution and diversity of individual and group activities & 3.2 & 12.4 & 28.8 & 28.8 & 26.8 \\
\hline Upgrading charm and beautiful squares (flooring, lighting, elements, etc.) & 1.2 & 4.4 & 16.4 & 37.2 & 40.8 \\
\hline $\begin{array}{l}\text { Restoration and preservation of old monuments and the creation of artistic and } \\
\text { recreational use }\end{array}$ & & 4.0 & 17.2 & 29.2 & 49.6 \\
\hline Access to the street (permeability) and park location & 2.4 & 7.6 & 28.8 & 32.4 & 28.8 \\
\hline Urban waste management and cleanliness of public spaces & 0.8 & 6.8 & 21.6 & 34.8 & 36.0 \\
\hline $\begin{array}{l}\text { Organizing and business use annoying (blacksmith, oil changes, } \\
\text { mechanical) }\end{array}$ & 0.8 & 5.2 & 23.6 & 38.4 & 32.0 \\
\hline $\begin{array}{l}\text { Organizing and beautify the city uses and public facilities (toilets, drinking } \\
\text { water, kiosks, etc.) }\end{array}$ & - & 5.2 & 15.6 & 33.2 & 46.0 \\
\hline
\end{tabular}

Table 5. Results of Kolmogorov-Smirnov test for normality of the distribution of scores.

\begin{tabular}{llll}
\hline Variable & Level of significance & Z statistics Kolmogorov-Smirnoff & Number \\
\hline $\begin{array}{l}\text { Effect of visual pollution and heterogeneity of urban } \\
\text { vitality }\end{array}$ & 0.084 & 2.236 & 250 \\
$\begin{array}{l}\text { Effect of improving the quality and aesthetics and } \\
\text { identity of public spaces on urban vitality }\end{array}$ & 0.160 & 1.124 & 250 \\
\begin{tabular}{l} 
Satisfaction level \\
\hline
\end{tabular} & 0.072 & 1.879 & 250 \\
\hline
\end{tabular}

(H1) the effect of improving environmental quality, aesthetics and identity of public spaces on the urban vitality is significantly more than average; the promotion of quality and aesthetics and identity of urban space increases the vitality (see Table 6). 
Table 6. Results of t-test one sample for research assumptions.

\begin{tabular}{cccccccc}
\hline & \multicolumn{5}{c}{ Test N. 3 } & & \\
\hline Variable & $\begin{array}{c}\text { Mean difference } \\
\text { between the } \\
\text { amount of test }\end{array}$ & $\begin{array}{c}\text { Significance } \\
\text { level }\end{array}$ & $\begin{array}{c}\text { Degrees of } \\
\text { freedom }\end{array}$ & T & SD & Mean & Number \\
\hline $\begin{array}{c}\text { Effects of pollution and visual } \\
\text { diversity with beauty, charm and } \\
\text { vitality of urban space }\end{array}$ & 1.19600 & 0.000 & 249 & 36.416 & 0.51929 & 4.1960 & 250 \\
$\begin{array}{c}\text { Effect of improving the quality of } \\
\text { environment, visual beauty and the } \\
\text { vitality of urban identity }\end{array}$ & 1.04291 & 0.000 & 249 & 0.49880 & 0.3359 & 0.4294 & 250 \\
\hline
\end{tabular}

\section{Summary}

\subsection{Results}

Quality and vitality has a meaning beyond urban areas that can be investigated at different levels such as environmental quality, sustainability, public welfare, visual, compliance, compatibility, performance, justice, security, inclusion. Based on the findings, vitality can be divided into two levels of macro and micro: the macro level consists of spatial, cultural, economic, aesthetic, social and micro level consists of visual comfort, space and component non-physical (activity) that their subsets of these factors are discussed also in place. For example, cosmetic components include indicators of urban art and visual delight and itself includes a subset of satisfaction, attractiveness and vitality.

Charming spaces, beautiful and lively spaces are those that will attract and satisfy a wide range of subjects (in terms of age and sex) according the diversity of visual and calm environment, which requires the attention to human and the needs of users (citizens) in the creating high quality public spaces.

To designing the proposed model, urban art, urban design human-centered and component visual comfort (color, light, symbol, visual) were considered as a first priority of beauty, vitality, attractiveness and vitality of urban public spaces which leads to the identity, improve the quality of urban environment, and beauty and attractiveness of these spaces which in turn will lead to citizen satisfaction and it is necessary to consider the improving the quality of aesthetic and identity-oriented space with a focus on urban art to be considered as factors affecting the vitality and linked with urban spaces.

\subsection{Suggestion}

With regard to the subject and importance of beauty and vitality in urban areas, it has been tried to achieve the important objectives of this study be set. The present study suggestions are in three levels of micro, middle, and macro which are comprehensive and besides the logical and fundamental relationship are complementary.

Micro level: at the micro level, the goal is to plan special offers (details) to organize and removing pollution and visual disturbances in the study area in different aspects (visual, color, light, Symbol) and in terms of objectives, policies, strategies.

Middle level: According to the goals of the present study are searched in places and spaces within urban and as the "vitality" is the main feature of sidewalk and place of interaction, leisure, recreation and vitality, shop, relax and sidewalk that attract a wide range of citizens; to enhance the quality of vitality, removing visual pollution, beauty and identity of the area under study, creating a link between urban vitality and components of visual relaxing that can be complementary and visual comfort promote besides the beauty, charm, vitality and quality of urban space and it seems rational.

Macro level: Beautification Master Plan as a unifying and comprehensive urban beautification which includes elements of visual comfort is proposed; a plan that in addition the city's image quality considers quality [17]. while bind cross-sectional and temporary designs of beautification and put them in a logical and consistent with each other, is applicable to the case that the final product is creating the quality, attractive, beautiful, and lively urban spaces that citizens take pleasure in it and find their historical, cultural, and recovered identity of their own city and feel the sense of belonging and vitality in all aspects of urban spaces.

\subsection{Conclusion}

According to the concepts studied, designing theoretical foundations, analysis and evaluation of the present situ- 
ation (where are we?), confusion, disparity and visual pollution have a direct influence on the environment and reducing quality environment, charm, satisfaction, joy and vitality of urban areas but as the urban vitality and multidimensional concept is due to various factors and has a multi-dimension meaning, its achievement is dependent on its logical relationship with the parameters of quality of urban design which is the missing link with the citizens and the city triangle with urban management and urban spaces and the components of visual relaxing in city spaces.

\section{References}

[1] Beautification Organization of Tehran (2012) Urban Art. Institute of Shahr Publication, Tehran.

[2] Goodey, B. (1993) Two Gentlemen in Verona: The Qualities of Urban Design, Strrewise.

[3] Coleman J. (1987) Opportunities for Inviting in Urban Design Education. Australian Planner, 1, 32.

[4] Jacobs, J. (1961) The Death \& Life of Great American Cities. London Cape.

[5] Lynch, K. (2004) Vision City. 6th Edition, Translated by M. Mozayani, Tehran University Press, Tehran.

[6] Gehl, J. (2004) Public Spaces, Public Life. Danish Architectural Press, Copenhagen.

[7] Dandis, D. (2009) The Principles of Visual Literacy. Translated by M. Sepehr, Soroush Publication, Tehran.

[8] Carmona, M. (2009) Public Places and Spaces. Translated by Gharaei F. et al., Tehran Art University Publication, Tehran.

[9] Tibaldez, F. (2004) Citizen-Oriented Urban Development, Modernization of Public Areas in Cities and Urban Environments. Translated by Mohammad Ahmadinejad, Khak Publication, Isfahan.

[10] Kiwi, R. and Kampenhood, L.V. (2007) Research Methods in the Social Sciences. Translated by Nik Abdul Hussein Gohar, Tutya Publication, Tehran.

[11] Golkar, K. (2007) The Concept of Vitality in Urban Design Quality. Journal of the Saffeh, Tehran, 44, 56.

[12] Pakzad, J. and Suri, E. (2011) Guide of Lighting Urban Places. Utopia Publication, Tehran.

[13] Loshchinsky, N. (2008) Landscape Planting Design: Professional Approach to Garden Design. Translated by M. Kafi, Aeezh Publication, Tehran.

[14] Lynch, K. (1997) Theory of Good City. Translated by Sh. Bahraini, Tehran University Press, Tehran.

[15] Landry, C. (2000) Uban Vitality: A New Source of Urban Competitiveness. Prince Claus Fund Journal, Archive Issue Urban Vitality-Urban Heroes.

[16] Nelessen, A.C. (1994) Visions for a New American Dream. APA Planner Press, Chicago.

[17] City of Turlock, California (2010) Beautification Master Plan, Landscape \& Signage. 